\title{
The First and Second Dissociation Constants of Subtilisin BPN'-Plasminostreptin Complex Determined by a Polarographic Method, and the Effects of $\mathrm{pH}$ on Them
}

\author{
Kenji Kano, Tomonori Konse, Motoko OKada, ${ }^{\dagger}$ \\ Tanekazu Kubota, Sachiko IBE, ${ }^{*}{ }^{\dagger \dagger}$ Tokuji IKEDA* \\ and Mitsugi SENDA* \\ Gifu Pharmaceutical University, \\ 6-1 Mitahora-higashi 5-chome, Gifu 502, Japan \\ *Department of Agricultural Chemistry, Faculty of Agriculture, \\ Kyoto University, Kyoto 606, Japan
}

Received December 1, 1983

\begin{abstract}
A polarographic method based on the Brdička current (the polarographic catalytic hydrogen evolution current produced by proteins in the presence of cobalt salts) was applied to direct titration of subtilisin BPN $^{\prime}$ (S.BPN') with plasminostreptin (PS) at a concentration level of $10^{-8} \mathrm{M}$. The first and second dissociation constants of the S.BPN'-PS complex were determined by fitting theoretical curves to the titration data, in which the multiple equilibria involving microscopically distinct forms of S.BPN'-PS complex were taken into account. The intrinsic free energy change in the first binding of S.BPN' to dimeric PS was larger than that in the second binding. The dependence of the microscopic dissociation constants of S.BPN'-PS complex on $\mathrm{pH}$ indicates the participation of ionizable groups of $\mathrm{p} K_{\mathrm{a}} 8.0$ and 9.4 in the complex formation. The repulsive effect between negatively charged molecules of S.BPN' and PS in the complex formation at elevated $\mathrm{pH}$ is suggested.
\end{abstract}

Plasminostreptin (PS $)^{1)}$ is a protein proteinase inhibitor of microbial origin, which inhibits plasmin [EC 3.4.21.7], trypsin [EC 3.4.21.4], subtilisin $\mathrm{BPN}^{\prime} \quad\left(\mathrm{S} . \mathrm{BPN}^{\prime}\right) \quad$ [EC 3.4.21.14], and other microbial alkaline proteinases. The amino acid sequence of PS is identical with that of Streptomyces subtilisin inhibitor (SSI) at about $70 \%$ of the positions. ${ }^{2)}$ PS as well as SSI consists of two identical subunits and is able to bind one molecule of proteinase per subunit of the inhibitor to form enzyme-inhibitor complexes, for which an accurate determination of the dissociation constants has been the subject of intensive studies. $^{3,4)}$ In previous papers, ${ }^{5)}$ we have shown that the polarographic method based on the Brdička current can be successfully applied to direct titration of S.BPN' with SSI or PS at the concentration level of $10^{-7}$ to $10^{-10} \mathrm{M}$, and determined the first and second dissociation constants of dimeric S.BPN'-SSI complex. In this study, we have determined the microscopic dissociation constants of S.BPN'-PS complex using a tast polarographic method, and investigated the effects of $\mathrm{pH}$ on the microscopic dissociation constants.

\section{MATERIALS AND METHODS}

Materials. Plasminostreptin (PS) was donated by Dr. A. Kakinuma of Takeda Chemical Industries, Ltd. and subtilisin BPN' (S.BPN') was commercially obtained (Sigma Chemical Co., lot No. 89C-0528), and both were used as received. The purity of the enzyme preparation was determined to be $75.0 \%$ according to the method of Inouye et $a l^{6)}$ All other chemicals were of reagent grade quality.

$\dagger$ Present address: Laboratory of Drug Metabolism and Analytical Research, Otsuka Pharmaceutical Co., Ltd., Kawauchi-cho, Tokushima 771-01, Japan.

${ }^{\dagger \dagger}$ Present address: Tokyo Agriculture and Forestry Inspection Institute, Minato-ku, Tokyo 108, Japan. 
Apparatus. Polarograms were recorded in a tast d.c. mode with a Yanagimoto P-1000 voltammetric analyzer, equipped with a Watanabe WX-4401 X-Y recorder. Two dropping mercury electrodes (DME) were used. Their characteristics were $m=0.852 \mathrm{mg} \mathrm{s}^{-1}$ and $t=11.08 \mathrm{~s}$ at $h=$ $50.0 \mathrm{cmHg}$ for DME I and $m=1.471 \mathrm{mg} \mathrm{s}^{-1}$ and $t=4.25 \mathrm{~s}$ at $h=48.3 \mathrm{cmHg}$ for DME II, both at $-1.5 \mathrm{~V}$ in ammoniacal buffer.

Electrochemical measurements. As the base solutions, $0.2 \mathrm{M}$ Tris- $\mathrm{HCl}$ buffer ( $\mathrm{pH} 7.6 \sim 8.5$ ), and $0.2 \mathrm{M} \mathrm{NH}_{3}-$ $\mathrm{NH}_{4} \mathrm{Cl}$ buffer ( $\mathrm{pH} 8.8 \sim 10.2$ ), both containing $2 \times 10^{-4} \mathrm{M}$ $\mathrm{Co}\left(\mathrm{NH}_{3}\right)_{6} \mathrm{Cl}_{3}$, were used. The ionic strength of the base solution was adjusted to $0.2 \mathrm{M}$ with $\mathrm{KCl}$. The Brdička current was measured from the limiting current of cobalt reduction. Amperometric titration was performed at a fixed potential, usually at $-1.35 \mathrm{~V}$. All potentials were measured against a saturated calomel electrode (SCE). Other details of electrochemical measurements have been described in a previous paper. ${ }^{5 b)}$

\section{RESULTS AND DISCUSSION}

Brdička current of $P S$ and S.BPN'-PS complex

In d.c. polarography, PS gave a well defined Brdička wave (Fig. 1, curve 2). The Brdička current, usually measured at $-1.35 \mathrm{~V}$, increased linearly with the concentration of PS up to $8.0 \times 10^{-7} \mathrm{M}$ at $\mathrm{pH}$ 8.0. S.BPN' also gave a small wave, but its wave height was very much smaller than that of PS (Fig. 1, curve 1). When S.BPN' was added to a PS solution, the Brdička wave decreased in height as shown, for example, by curve 3 in Fig. 1. It has been shown $^{7)}$ that generally the adsorption of protein on a mercury electrode surface is strong and the adsorption process is controlled by diffusion at the potential more positive than $-1.5 \mathrm{~V}$. Under the conditions of diffusioncontrolled adsorption, the Brdička current increases linearly with the bulk concentration of protein and the Brdička current, $i_{\mathrm{B}}$, produced by a mixture of proteins is given by the sum of the Brdička currents, $\left(i_{\mathrm{B}}\right)_{\mathrm{j}}$, produced by each protein, $\mathrm{j}$.

$$
i_{\mathrm{B}}=\Sigma\left(i_{\mathrm{B}}\right)_{\mathrm{j}}=\Sigma \kappa_{\mathrm{j}}[\mathrm{j}]
$$

where $\kappa_{\mathrm{j}}$ is the proportionality constant converting the concentration of the protein $\mathrm{j},[\mathrm{j}]$, to its Brdička current $\left(i_{\mathrm{B}}\right)_{\mathrm{j}}$. Accordingly, the

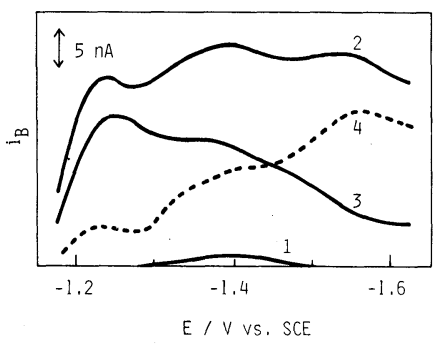

FIG. 1. Polarographic Tast Waves (with DME I) of (1)

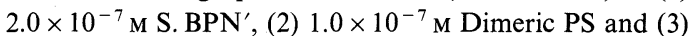
$2.0 \times 10^{-7} \mathrm{M}$ S. BPN $+1.0 \times 10^{-7} \mathrm{M}$ Dimeric PS in the Base Solution of $\mathrm{pH} 8.0$.

The current was measured from the cobalt limiting current of the base solution. The broken line (curve 4) represents the $\Delta i_{\mathrm{B}}\left([\mathrm{E}]_{0},\left[\mathrm{I}_{2}\right]_{0}\right) v s$. potential curve for the mixture of $2.0 \times 10^{-7} \mathrm{M} \mathrm{S}$. BPN' and $1.0 \times 10^{-7} \mathrm{M}$ dimeric PS.

decrease of the Brdička wave height of PS with the addition of S.BPN' should be attributed to the formation of a complex of PS with S.BPN', with the $\kappa$ value of the complex being much smaller than $\kappa_{\mathrm{PS}} \cdot{ }^{5 \mathrm{a}}$

Curve 4 in Fig. 1 represents a difference Brdička current, $\Delta i_{\mathrm{B}}\left([\mathrm{E}]_{0},\left[\mathrm{I}_{2}\right]_{0}\right)$, defined by Eq. (2);

$$
\begin{aligned}
\Delta i_{\mathrm{B}}\left([\mathrm{E}]_{0},\left[\mathrm{I}_{2}\right]_{0}\right)= & i_{\mathrm{B}}\left([\mathrm{E}]_{0}\right)+i_{\mathrm{B}}\left(\left[\mathrm{I}_{2}\right]_{0}\right) \\
& -i_{\mathrm{B}}\left([\mathrm{E}]_{0}+\left[\mathrm{I}_{2}\right]_{0}\right)
\end{aligned}
$$

where $i_{\mathrm{B}}\left([\mathrm{E}]_{0}\right), i_{\mathrm{B}}\left(\left[\mathrm{I}_{2}\right]_{0}\right)$, and $i_{\mathrm{B}}\left([\mathrm{E}]_{0}+\left[\mathrm{I}_{2}\right]_{0}\right)$ are the Brdička currents produced by the enzyme $\mathrm{E}$ (S.BPN' in our case) at the concentration of $[E]_{0}$, the dimeric inhibitor $\mathrm{I}_{2}$ (dimeric PS in our case) at the concentration of $\left[\mathrm{I}_{2}\right]_{0}$, and their mixture at the concentrations of $[\mathrm{E}]_{0}$ and $\left[\mathrm{I}_{2}\right]_{0}$, respectively. We further define the relative difference Brdička current, $\Delta I_{\mathrm{B}}\left([\mathrm{E}]_{0},\left[\mathrm{I}_{2}\right]_{0}\right)$, by

$$
\begin{aligned}
& \Delta I_{\mathrm{B}}\left([\mathrm{E}]_{0},\left[\mathrm{I}_{2}\right]_{0}\right) \\
& \quad=\Delta i_{\mathrm{B}}\left([\mathrm{E}]_{0},\left[\mathrm{I}_{2}\right]_{0}\right) / i_{\mathrm{B}}\left(\left[\mathrm{I}_{2}\right]_{\text {equiv }}\right)
\end{aligned}
$$

where $i_{\mathrm{B}}\left(\left[\mathrm{I}_{2}\right]_{\text {equiv }}\right)$ is the Brdička current produced by the inhibitor at the concentration of $\left[\mathrm{I}_{2}\right]_{\text {equiv }}$ which is equal to $[\mathrm{E}]_{0} / 2$. We titrated $2.86 \times 10^{-7}$ M S.BPN' with PS in a Tris buffer of $\mathrm{pH} 8.5$ amperometrically by measuring the Brdička current heights at $-1.35 \mathrm{~V}$. The titration curve is shown in Fig. 2, where $\Delta I_{\mathrm{B}}\left([\mathrm{E}]_{0}\right.$, $\left[\mathrm{I}_{2}\right]_{0}$ ) is plotted against $2\left[\mathrm{I}_{2}\right]_{0} /[\mathrm{E}]_{0},\left[\mathrm{I}_{2}\right]_{0}$ being 


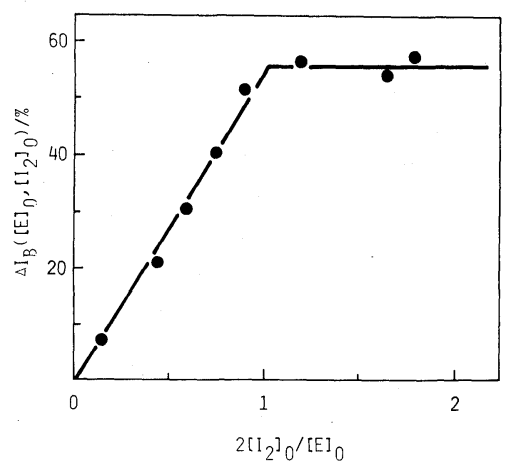

FIG. 2. Polarographic Titration Curve $\left(\Delta I_{\mathrm{B}}\left([\mathrm{E}]_{0},\left[I_{2}\right]_{0}\right)\right.$ vs. $2\left[\mathrm{I}_{2}\right]_{0} /[\mathrm{E}]_{0}$ plot) of $\mathrm{S}$. $\mathrm{BPN}^{\prime}$ with $\mathrm{PS}$ at $[\mathrm{E}]_{0}=2.86 \times$ $10^{-7} \mathrm{M}$ and at $\mathrm{pH} 8.5, I=0.2 \mathrm{M}$ and $25^{\circ} \mathrm{C}$.

The currents were measured at $-1.35 \mathrm{~V}$ with DME I.

the amount in $\mathrm{M}$ of dimeric PS added and $[\mathrm{E}]_{0}=2.86 \times 10^{-7} \mathrm{M}$. The $\Delta I_{\mathrm{B}}\left([\mathrm{E}]_{0},\left[\mathrm{I}_{2}\right]_{0}\right)$ value initially increased linear with $2\left[\mathrm{I}_{2}\right]_{0} /[\mathrm{E}]_{0}$ and approached a certain maximum value, $\Delta I_{\mathrm{B}}\left([\mathrm{E}]_{0},\left[\mathrm{I}_{2}\right]_{0}\right)^{\max }$, with an inflection point at $2\left[\mathrm{I}_{2}\right]_{0} /[\mathrm{E}]=1.0$, indicating that the complex formation between S.BPN' and PS proceeds according to

$$
\begin{aligned}
2 \mathrm{~S} . \mathrm{BPN}^{\prime} & +(\mathrm{PS})_{2} \\
= & \left(\mathrm{S} . \mathrm{BPN}^{\prime}\right)(\mathrm{PS})_{2}\left({\mathrm{~S} . B P N^{\prime}}^{\prime}\right)
\end{aligned}
$$

Here it is assumed that the complex is present as a dimeric S.BPN'-PS complex in analogy with the formation of S.BPN'-SSI complex, ${ }^{5 b}$ ) though Kakinuma et al. ${ }^{1)}$ have reported that a monomeric trypsin-PS complex is also formed under certain conditions in Tris buffer of $\mathrm{pH}$ 7.5.

Determination of the dissociation constants of

\section{$S . B P N^{\prime}-P S$ complex}

Titration of S.BPN' with PS was also carried out at $[\mathrm{E}]_{0}=4.56 \times 10^{-8} \mathrm{M}$ in Tris buffer of $\mathrm{pH}$ 8.5. A representative $\Delta I_{\mathrm{B}}\left([\mathrm{E}]_{0},\left[\mathrm{I}_{2}\right]_{0}\right) v s$. $2\left[\mathrm{I}_{2}\right]_{0} /[\mathrm{E}]_{0}$.plot is shown in Fig. 3. The curve changes gradually near the equivalent point $\left(2\left[\mathrm{I}_{2}\right]_{0} /[\mathrm{E}]_{0}=1\right)$, indicating that the dissociation of the S.BPN'-PS complex is not negligible at such a low concentration of proteins.

For the dimeric S.BPN'-PS complex, we consider that a bifunctional dimeric PS, $\mathrm{I}_{2}$ successively binds two molecules of S.BPN', E,

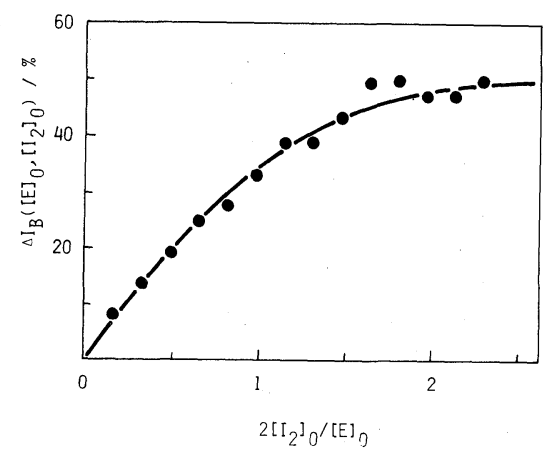

Fig. 3. Polarographic Titration Curve $\left(\Delta I_{\mathrm{B}}\left([\mathrm{E}]_{0},\left[\mathrm{I}_{2}\right]_{0}\right)\right.$ vs. $2\left[\mathrm{I}_{2}\right]_{0} /[\mathrm{E}]_{0}$ plot) of $\mathrm{S}$. $\mathrm{BPN}^{\prime}$ with $\mathrm{PS}$ at $[\mathrm{E}]_{0}=4.56 \times$ $10^{-8} \mathrm{M}$ and at $\mathrm{pH} 8.5, I=0.2 \mathrm{M}$ and $25^{\circ} \mathrm{C}$.

The currents were measured at $-1.35 \mathrm{~V}$ with DME I. The solid line is the theoretical curve calculated on values of $K_{1}{ }^{\prime}=6.7 \times 10^{-9} \mathrm{M}, K_{2}{ }^{\prime}=1.2 \times 10^{-8} \mathrm{M}$ and $\Delta \kappa=0.55$ according to Eqs. (6) and (8).

to form enzyme-inhibitor complexes, according to the following scheme ${ }^{5)}$ :

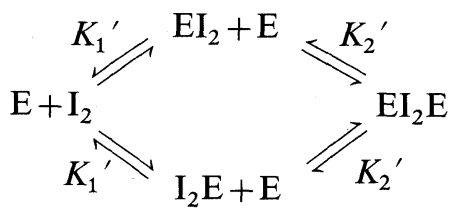

where $K_{1}{ }^{\prime}$ and $K_{2}{ }^{\prime}$ are the microscopic dissociation constants. ${ }^{8)}$ Then, as described in a previous paper, ${ }^{5 \mathrm{~b})} \Delta I_{\mathrm{B}}\left([\mathrm{E}]_{0},\left[\mathrm{I}_{2}\right]_{0}\right)$ for given analytical concentrations of $\mathrm{E}$ and $\mathrm{I}_{2},[\mathrm{E}]_{0}$ and $\left[\mathrm{I}_{2}\right]_{0}$, respectively, is expressed by

$$
\Delta I_{\mathrm{B}}\left([\mathrm{E}]_{0},\left[\mathrm{I}_{2}\right]_{0}\right)=\Delta \kappa\left([\mathrm{E}]_{0}-[\mathrm{E}]\right) /[\mathrm{E}]_{0}
$$

with

$$
\Delta \kappa=\left(2 \kappa_{\mathrm{E}}+\kappa_{\mathrm{I}_{2}}-\kappa_{\mathrm{EI}_{2} \mathrm{E}}\right) / \kappa_{\mathrm{I}_{2}}
$$

Here $\kappa_{\mathrm{E}}, \kappa_{\mathrm{I}_{2}}$ and $\kappa_{\mathrm{EI}_{2} \mathrm{E}}$ are the proportionality constants converting the protein concentrations to the Brdička current intensities for $\mathrm{E}, \mathrm{I}_{2}$ and $\mathrm{EI}_{2} \mathrm{E}$, respectively (see Eq. (1)). The proportionality constants for $\mathrm{EI}_{2}$ and $\mathrm{I}_{2} \mathrm{E}, \kappa_{\mathrm{EI}_{2}}$ and $\kappa_{\mathrm{I}_{2} \mathrm{E}}$, are assumed to be $\kappa_{\mathrm{EI}_{2}}=\kappa_{\mathrm{I}_{2} \mathrm{E}}=$ $\left(\kappa_{\mathrm{I}_{2}}+\kappa_{\mathrm{EI}_{2} \mathrm{E}}\right) / 2$. [E] is the concentration of free enzyme and is given by the solution of Eq. (8);

$$
\begin{aligned}
{[\mathrm{E}]^{3}+\left(2\left[\mathrm{I}_{2}\right]_{0}-[\mathrm{E}]_{0}+2 K_{2}{ }^{\prime}\right)[\mathrm{E}]^{2} } & \\
+ & K_{2}{ }^{\prime}\left(2\left[\mathrm{I}_{2}\right]_{0}-2[\mathrm{E}]_{0}+K_{1}{ }^{\prime}\right)[\mathrm{E}] \\
& -K_{1}{ }^{\prime} K_{2}{ }^{\prime}[\mathrm{E}]_{0}=0
\end{aligned}
$$


We determined $\Delta I_{\mathrm{B}}\left([\mathrm{E}]_{0},\left[\mathrm{I}_{2}\right]_{0}\right)$ for different $\left[\mathrm{I}_{2}\right]_{0}$ 's $\left(0.37 \sim 5.22 \times 10^{-8} \mathrm{M}\right)$ for a constant $[\mathrm{E}]_{0}$ $\left(4.56 \times 10^{-8} \mathrm{M}\right)$ at $\mathrm{pH} 8.5$ and fitted the $\Delta I_{\mathrm{B}}\left([\mathrm{E}]_{0},\left[\mathrm{I}_{2}\right]_{0}\right)$ vs. $2\left[\mathrm{I}_{2}\right]_{0} /[\mathrm{E}]_{0}$ plot (Fig. 3) to the theoretical curve represented by Eqs. (6) and (8) by adjusting the three parameters $K_{1}{ }^{\prime}, K_{2}{ }^{\prime}$ and $\Delta \kappa$ using Facom M-200 computers in the Data Processing Centers of Nagoya University and Kyoto University. The results of nonlinear least-squares analysis using the SALS $\operatorname{program}^{9)} \quad$ were $\quad K_{1}{ }^{\prime}=(6.7 \pm 4.8) \times 10^{-9} \mathrm{M}$, $K_{2}{ }^{\prime}=(1.2 \pm 0.7) \times 10^{-8} \mathrm{M}$ and $\Delta \kappa=0.55 \pm 0.11$. The solid line in Fig. 3 is a regression curve calculated on values of $K_{1}{ }^{\prime}=6.7 \times 10^{-9} \mathrm{M}$, $K_{2}{ }^{\prime}=1.2 \times 10^{-8} \mathrm{M}$ and $\Delta \kappa=0.55$.

Equation (6) shows that $\Delta I_{\mathrm{B}}\left([\mathrm{E}]_{0},\left[\mathrm{I}_{2}\right]_{0}\right)$ approaches $\Delta \kappa$ at $[\mathrm{E}] /[\mathrm{E}]_{0} \rightarrow 0$. On the other hand, $\Delta I_{\mathrm{B}}\left([\mathrm{E}]_{0},\left[\mathrm{I}_{2}\right]_{0}\right)$ approaches a maximum value, $\Delta I_{\mathrm{B}}\left([\mathrm{E}]_{0},\left[\mathrm{I}_{2}\right]_{0}\right)^{\max }$, as $2\left[\mathrm{I}_{2}\right]_{0} /[\mathrm{E}]_{0}$ exceeds the equivalent point greatly (see Figs. 2 and 3). Since $[\mathrm{E}] /[\mathrm{E}]_{0} \ll 0$ when $2\left[\mathrm{I}_{2}\right]_{0} /[\mathrm{E}]_{0} \gg 1, \Delta \kappa$ must be equal to $\Delta I_{\mathrm{B}}\left([\mathrm{E}]_{0},\left[\mathrm{I}_{2}\right]_{0}\right)^{\max }$. The agreement between the adjusted $\Delta \kappa$ value of 0.55 and the $\Delta I_{\mathrm{B}}\left([\mathrm{E}]_{0},\left[\mathrm{I}_{2}\right]_{0}\right)^{\mathrm{max}}$ value of 0.55 estimated from the titration curve in Fig. 2 is excellent.

\section{Effects of $p H$ on the dissociation constants of} S.BPN'-PS complex

The microscopic dissociation constants of S.BPN'-PS complex were determined in the way described above in buffer solutions of $\mathrm{pH}$ 7.6 to 10.2. The results are shown in Fig. 4. Let us consider that the enzyme and the complexes exist in two states of ionization as follows:

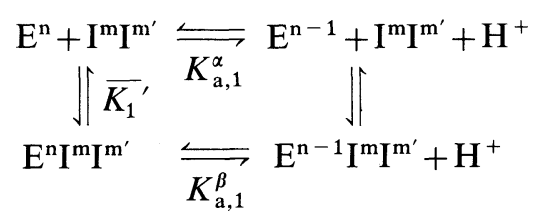

for the first step of complex formation and

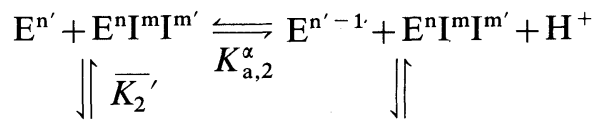

$$
\begin{aligned}
& \mathrm{E}^{\mathrm{n}} \mathrm{I}^{\mathrm{m}} \mathrm{I}^{\mathrm{m}^{\prime}} \mathrm{E}^{\mathrm{n}^{\prime}} \underset{K_{\mathrm{a}, 2}^{\beta}}{\leftrightharpoons} \mathrm{E}^{\mathrm{n}} \mathrm{I}^{\mathrm{m}} \mathrm{I}^{\mathrm{m}^{\prime}} \mathrm{E}^{\mathrm{n}^{\prime}-1}+\mathrm{H}^{+}
\end{aligned}
$$

for the second. In this case, $K_{\mathrm{a}, 1}^{\alpha}$ and $K_{\mathrm{a}, 2}^{\alpha}$

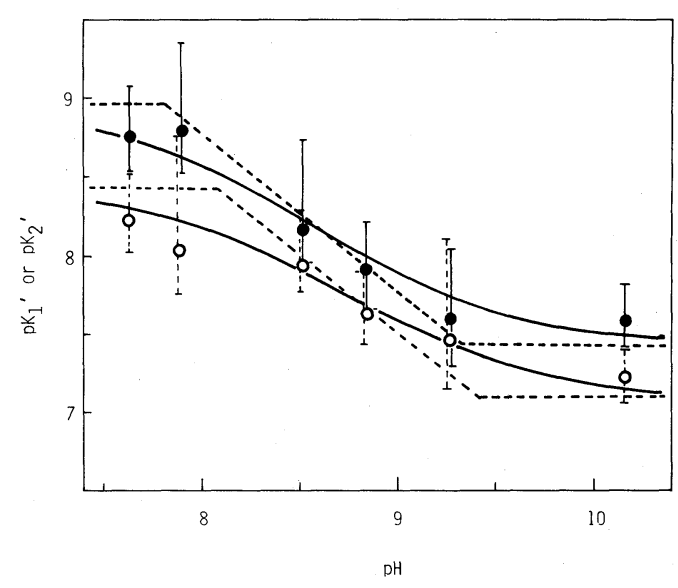

FIG. 4. Effects of $\mathrm{pH}$ on $\mathrm{p} K_{1}{ }^{\prime}\left(=-\log K_{1}{ }^{\prime}\right)(\bigcirc)$ and $\mathrm{p} K_{2}{ }^{\prime}\left(=-\log K_{2}{ }^{\prime}\right)(\bigcirc)$ of S. BPN'-PS Complex.

The vertical bars indicate the standard deviation. The solid lines are the theoretical curves calculated on values of $\mathrm{p} \bar{K}_{1}{ }^{\prime}=8.96, \mathrm{p} K_{\mathrm{a}, 1}^{\alpha}=7.81$ and $\mathrm{p} K_{\mathrm{a}, 1}^{\beta}=9.34$ according to Eq. (13) for the upper curve, and $\mathrm{p} \bar{K}_{2}{ }^{\prime}=8.34, \mathrm{p} K_{\mathrm{a}, 2}^{\alpha}=8.08$ and $\mathrm{p} K_{\mathrm{a}, 2}^{\beta}=9.42$ according to Eq. (14) for the lower curve. The broken lines represent guide lines of Dixon plots.

should be equal. Alternatively, we may consider that the inhibitor and the complexes exist in two states of ionization as follows,

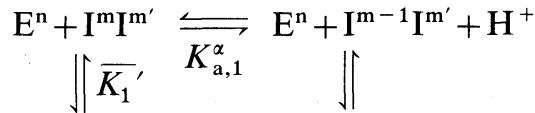

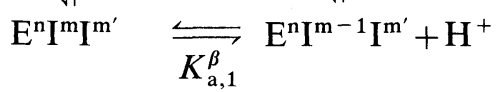

for the first step of complex formation and

$$
\begin{aligned}
& \mathrm{E}^{\mathrm{n}^{\prime}}+\mathrm{E}^{\mathrm{n}} \mathrm{I}^{\mathrm{m}} \mathrm{I}^{\mathrm{m}^{\prime}} \leftrightharpoons \mathrm{E}^{\mathrm{n}^{\prime}}+\mathrm{E}^{\mathrm{n}} \mathrm{I}^{\mathrm{m}} \mathrm{I}^{\mathrm{m}^{\prime}-1}+\mathrm{H}^{+} \\
& \left\|\overline{K_{2}^{\prime}} \quad K_{\mathrm{a}, 2}^{\alpha} \quad\right\| \\
& \mathrm{E}^{\mathrm{n}} \mathrm{I}^{\mathrm{m}} \mathrm{I}^{\mathrm{m}^{\prime}} \mathrm{E}^{\mathrm{n}^{\prime}} \underset{K_{\mathrm{a}, 2}^{\beta}}{\leftrightharpoons} \mathrm{E}^{\mathrm{n}} \mathrm{I}^{\mathrm{m}} \mathrm{I}^{\mathrm{m}^{\prime}-1} \mathrm{E}^{\mathrm{n}^{\prime}}+\mathrm{H}^{+}
\end{aligned}
$$

for the second. Here the subscripts $n, n^{\prime}, m$ and $\mathrm{m}^{\prime}$ represent the number of ionizable protons in the protein species and $K_{\mathrm{a}, 1}^{\alpha}, K_{\mathrm{a}, 1}^{\beta}$, $K_{\mathrm{a}, 2}^{\alpha}$ and $K_{\mathrm{a}, 2}^{\beta}$ are the acid dissociation constants of the respective ionizable groups. These two schemes $(9,10)$ and $(11,12)$ result in the same $\mathrm{pH}$-dependence of the first and second apparent dissociation constants, $\mathrm{p} K_{1}{ }^{\prime}$ and $\mathrm{p} K_{2}{ }^{\prime}$, respectively, as given by 


$$
\begin{aligned}
\mathrm{p} K_{1}{ }^{\prime}= & \mathrm{p} \overline{K_{1}{ }^{\prime}}+\log \left(1+10^{\mathrm{pH}-\mathrm{p} K_{a, 1}^{\beta}}\right) \\
& -\log \left(1+10^{\mathrm{pH}-\mathrm{p} K_{a, 1}^{\alpha}}\right) \\
\mathrm{p}{K_{2}}^{\prime}= & \mathrm{p}{\overline{K_{2}}}^{\prime}+\log \left(1+10^{\mathrm{pH}-\mathrm{p} K_{\mathrm{a}, 2}^{\beta}}\right) \\
& -\log \left(1+10^{\mathrm{pH}-\mathrm{p} K_{a, 2}^{\alpha}}\right)
\end{aligned}
$$

We fitted the curve represented by Eqs. (13) and (14) to the experimental plots of $\mathrm{p} K_{1}{ }^{\prime}$ and $\mathrm{p} K_{2}^{\prime}$ vs. $\mathrm{pH}$ by adjusting two sets of three parameters $\mathrm{p} \bar{K}_{1}{ }^{\prime}, \mathrm{p} K_{\mathrm{a}, 1}^{\alpha}$, and $\mathrm{p} K_{\mathrm{a}, 1}^{\beta}$, and $\mathrm{p} \bar{K}_{2}{ }^{\prime}$, $\mathrm{p} K_{1,2}^{\alpha}$, and $\mathrm{p} K_{\mathrm{a}, 2}^{\beta}$, respectively. The results of the non-linear least-squares analysis using the SALS program $^{9)}$ were $\mathrm{p} \overline{K_{1}}{ }^{\prime}=8.96 \pm 0.16$, $\mathrm{p} K_{\mathrm{a}, 1}^{\alpha}=7.81 \pm 0.22$, and $\mathrm{p} K_{\mathrm{a}, 1}^{\beta}=9.34 \pm 0.18$ for the first binding step (the upper curve), and $\mathrm{p} \overline{K_{2}}{ }^{\prime}=8.43 \pm 0.15, \quad \mathrm{p} K_{\mathrm{a}, 2}^{\alpha}=8.08 \pm 0.24, \quad$ and $\mathrm{p} K_{\mathrm{a}, 2}^{\beta}=9.42 \pm 0.23$ for the second binding step (the lower curve). The broken lines are socalled guide lines of Dixon plots, ${ }^{10)}$ with two inflection points at $\mathrm{p} K_{\mathrm{a}, 1}^{\alpha}=7.81$ and $\mathrm{p} K_{\mathrm{a}, 1}^{\beta}=$ 9.34, and $\mathrm{p} K_{\mathrm{a}, 2}^{\alpha}=8.08$ and $\mathrm{p} K_{\mathrm{a}, 2}^{\beta}=9.42$, respectively, for the upper and lower curves.

As seen in Fig. 4, $\mathrm{p} K_{1}{ }^{\prime}$ and $\mathrm{p} K_{2}{ }^{\prime}$ change with $\mathrm{pH}$, but the difference between them is nearly constant, independently of $\mathrm{pH}$; the mean difference $\mathrm{p} \overline{K_{1}}{ }^{\prime}-\mathrm{p} \overline{K_{2}}{ }^{\prime}=0.53$ implies that the free energy change of the first binding of the enzyme to the inhibitor is $3 \mathrm{~kJ} \mathrm{~mol}^{-1}$ larger than that of the second binding. A similar result has been obtained with S.BPN'-SSI complex with the difference of $7.1 \mathrm{~kJ} \mathrm{~mol}^{-1} .5 \mathrm{~b}$ )

$\mathrm{p} K_{\mathrm{a}, 1}^{\alpha}$ and $\mathrm{p} K_{\mathrm{a}, 1}^{\beta}$ coincide with $\mathrm{p} K_{\mathrm{a}, 2}^{\alpha}$ and $\mathrm{p} K_{\mathrm{a}, 2}^{\beta}$, respectively, within experimental error. This result can reasonably be explained by the above schemes, when we consider that in both the first and second bindings of S.BPN' to PS dimer the same ionizable group $\alpha$ with $\mathrm{p} K_{\mathrm{a}}^{\alpha}$ of about 8.0 and the same ionizable group $\beta$ with $\mathrm{p} K_{\mathrm{a}}^{\beta}$ of 9.4 are relevant to the ionization of the free enzyme (or inhibitor) and bound enzyme (or inhibitor), respectively. If we further assume that the group $\alpha$ and the group $\beta$ are an identical ionizable group, the above result indicates that $\mathrm{p} K_{\mathrm{a}}^{\alpha}$ of this ionizable group of S.BPN' (or PS) in the free $\left(\mathrm{p} K_{\mathrm{a}}^{\alpha} \simeq 8.0\right)$ is increased by 1.4 unit $\left(\mathrm{p} K_{\mathrm{a}}{ }^{\beta} \simeq 9.4\right)$ by the complex formation between S.BPN' and PS. Note that according to Inouye et al. ${ }^{11)} \mathrm{p} K_{\mathrm{a}}$ of a tyrosine in S.BPN' is shifted from 9.7 to 11.5 by the complex formation between S.BPN' and SSI. However, assignment of this ionizable group to a specific group is difficult. Among the candidates for this ionizable group, tyrosine $\left(\mathrm{p} K_{\mathrm{a}}=9.5 \sim 10.5\right)^{12)}$ and lysine $\left(\mathrm{p} K_{\mathrm{a}}=9.5 \sim 10.5\right)^{12)}$ have much higher $\mathrm{p} K_{\mathrm{a}}$ values, while histidine $\left(\mathrm{p} K_{\mathrm{a}}=5.0 \sim 7.4\right)^{12,13)}$ has a much lower $\mathrm{p} K_{\mathrm{a}}$ value than the observed value of $\mathrm{p} K_{\mathrm{a}}^{\alpha}$. Uehara et $a l^{3)}$ have reported the involvement of an ionizable group of $\mathrm{p} K_{\mathrm{a}} 8.5$ in the association of S.BPN ${ }^{\prime}$ and dimeric SSI, though these authors did not observe the second inflection point.

Another possible interpretation of the $\mathrm{pH}$ dependence of these dissociation constants is as follows. The isoelectric point (pI) of S.BPN' is $7.8,{ }^{14)}$ which is close to the value of $\mathrm{p} K_{\mathrm{a}}{ }^{\alpha}$. PS is always negatively charged in the $\mathrm{pH}$ range studied, since the pI of PS is 6.3. ${ }^{2)}$ Therefore the repulsion between the net negative charges of S.BPN' and PS may be a possible cause of the decreased affinity between them at elevated $\mathrm{pH}$.

Acknowledgments. We are grateful to Dr. A. Kakinuma, Takeda Chemical Industries, Ltd., for his kind gift of the PS preparation.

\section{REFERENCES}

1) A. Kakinuma, H. Sugino, N. Moriya and M. Isono, J. Biol. Chem., 253, 1529 (1978).

2) H. Sugino, A. Kakinuma and S. Iwanaga, J. Biol. Chem., 253, 1546 (1978).

3) Y. Uehara, B. Tonomura and K. Hiromi, $J$. Biochem., 84, 1195 (1978).

4) H. Sugino, N. Moriya, S. Nakagawa, A. Kakinuma, M. Isono and S. Iwanaga, J. Takeda Research Lab., 37, 119 (1978).

5) a) K. Kano, T. Ikeda and M. Senda, Agric. Biol. Chem., 45, 223 (1981); b) K. Kano, T. Ikeda and M. Senda, Agric. Biol. Chem., 47, 559 (1983).

6) K. Inouye, B. Tonomura, K. Hiromi, S. Sato and S. Murao, J. Biochem., 82, 961 (1977).

7) a) M. Senda, T. Ikeda and H. Kinoshita, Bioelectrochem. Bioenerg., 3, 253 (1976); b) M. Senda, T. Ikeda, T. Kakutani, K. Kano and H. Kinoshita, Bioelectrochem. Bioenerg., 8, 151 (1981).

8) R. B. Martin, "Introduction to Biophysical Chemistry," McGraw-HIll, New York, San 
Francisco, Toronto, London, 1964, p. 48.

9) T. Nakagawa and Y. Oyanagi, "SALS User's Manual," Computer Center of Tokyo University, 1979.

10) M. Dixon, E. C. Webb, C. J. R. Thorne and K. F. Tripton, "Enzymes," 3rd Ed., Longman Group Ltd., London, 1979, pp. 138 164 .

11) K. Inouye, B. Tonomura and K. Hiromi, $J$.
Biochem., 85, 1115 (1979).

12) Ref. 8, p. 79.

13) W. R. Finkenstadt and M. Jr. Laskowski, "Protein Inhibitors," ed. by H. Fritz, H. Tschesche, L. J. Greene and E. Truscheit, Springer-Verlag, Berlin, 1974, p. 389.

14) H. Matsubara, C. B. Kasper, D. M. Brown and E. L. Smith, J. Biol. Chem., 240, 1125 (1965). 